\title{
Genotype and planting depth effects on seed- ling vigor in sericea lespedeza
}

\author{
J. QIU AND J.A. MOSJIDIS
}

\begin{abstract}
Authors are former graduate research assistant and associate professor, Dept. Agronomy and Soils and Alabamo Agr. Exp. Sta., Auburn University 36849-5412.
\end{abstract}

\begin{abstract}
Sericea lespedeza [Lespedeza cuneata (Dumont de Courset) G. Don.] is a small-seeded forage legume that can improve forage quality and nitrogen content of interseeded pasturelands. Poor seedling vigor has caused interseeding failure. This study was conducted to determine the effects of genotype, planting depth, and their interaction on seedling vigor of sericea lespedeza in the field, and to determine if seedling traits measured in a growth chamber can be used to predict seedling growth in the field. Substantial variability was found among 54 sericea lespedeza genotypes for traits that can be used in a breeding program to improve seedling vigor. All seedling traits were correlated with each other, indicating a high proportionality existed among plant parts. Thus, any of the seedling traits measured could be used to represent seedling vigor. Genotypes 73-162-16, AU L2, AU L13, and 'Serala 76' outperformed other genotypes for most seedling traits under field and growth chamber conditions. Planting to a depth of $3 \mathrm{~cm}$ did not reduce seedling vigor, and therefore, may be recommended when there is insufficient moisture in the upper layer of sandy loam soils at planting. Although mesaurements taken in the growth chamber did not reliably predict field performance, information gathered in the growth chamber provides a good means of increasing the frequency of superior plants to be tested in the field.
\end{abstract}

Key Words: seedling growth, legumes, growth prediction, Lespedeza cuneata, seed weight

Successful stand establishment of forage species is highly dependent on seedling vigor as measured by seedling height or dry weight (Black 1957, Townsend 1979, Carren et al. 1987a, Carren et al. 1987b). Seed weight is a major plant determinant of seedling vigor (Beaveridge and Wilsie 1959, Wulff 1986) and planting depth is an environmental factor that may affect vigor in some species (Peiffer et al. 1972, Townsend and McGinnies 1972, Tischler and Voigt 1983) or may not have any effect in others (Black 1956, Williams 1967).

Sericea lespedeza [Lespedeza cuneata (Dumont de Courset) G. Don.] is a small-seeded forage legume that is often difficult to establish and displays poor seedling growth (Mosjidis 1990). Moore (1943) observed that as planting depth increased from 0.6 to $2.5 \mathrm{~cm}$, emergence decreased from 83 to $35 \%$ at 49 days after planting in a greenhouse study and from 58 to $18 \%$ at 30 days after planting in a field experiment. Seed size of 10 inbred lines had a significant and positive correlation with seedling height in a greenhouse study but was not consistently correlated with seedling height or forage yield in field studies (Cope 1966). Little is known regarding effect of planting depth or plant depth-genotype interactions on seedling vigor as measured by seedling traits such as stem, leaf or shoot dry weight in sericea lespedeza.

Journal Publication 3-923252

Manuscript accepted 19 Jan. 1993.
Selection for seedling vigor could be facilitated by laboratory procedures that provide a rapid and reliable prediction of seedling vigor under field conditions in forage breeding programs. Twamley (1967) found that forage yield of birdsfoot trefoil (Lotus corniculatus $\mathrm{L}$.) measured at $\mathbf{4 2}$ days after planting in a greenhouse provided a good prediction of seedling dry matter in the field. Cooper et al. (1980) reported that seedling height of birdsfoot trefoil measured at 3 days after planting in a growth chamber was highly correlated with field seedling vigor rating and forage yield. No information is available for sericea lespedeza regarding prediction of seedling growth in the field by seedling traits measured in controlled environments. The objectives of this study were to determine the effects of genotype, planting depth, and their interaction on seedling vigor of sericea lespedeza in the field, and to determine if seedling traits measured in the growth chamber can be used to predict seedling growth in the field.

\section{Materials and Methods}

Seeds of 54 sericea lespedeza genotypes, harvested at Tallassee, Ala., in 1988, were mechanically scarified with a Forsberg sample seed electric huller/scarifier (Forsberg Inc., Thief Rivers Falls, Minn. 56701)'. Seeds were placed in the huller/scarifier for 7 seconds, cleaned, and placed again in the huller/scarifier for 2 additional seconds. Seed weight of each genotype was determined by weighing 5 samples of 1,000 scarified seeds counted by an electronic counter (Model 850-2, The Old Mill Company, Savage Industrial Center, Savage, Md. 20763)' . A wide range of 1,000-seed weights $(1,333$ to $2,045 \mathrm{mg})$ was measured among the genotypes.

\section{Field Experiments}

Field experiments were conducted at Tallassee, Ala., on Hiwassee sandy loam soil (clayey, kaolinitic, thermic, typic Rhodudults). Seventy scarified seeds of each of the 54 genotypes were planted in a single row (4.6 m long and $0.5 \mathrm{~m}$ wide) at planting depths of 1 or 3 $\mathrm{cm}$ using a single-row cone seeder equipped with a packer wheel on 20 July 1990 and 18 April 1991 . Emerged seedlings were counted at 14,28 , and 42 days after planting. For most genotypes maximum emergence was observed at 42 days after planting and final emergence was therefore considered to be percent emergence at 42 days after planting. At 60 days after planting 5 random seedlings per genotype were harvested to ground level. Traits measured on each seedling were height and stem and leaf dry weights. Stem and leaf weights were added to give shoot weight. The study was conducted in a split plot arrangement of treatments in a randomized complete block design with 4 replications in each year. Main plots were the planting depths and the split plots were the genotypes.

\section{Growth Chamber Experiment}

Two scarified seeds of each of the 54 genotypes were planted 1

"Names of products are included for the benefit of the reader and do not imply endorsement or preferential treatment by the Alabama Agricultural Experiment Station, Auburn University. 
Table 1. Mean squares for emergence and seedling traits of 54 field-grown sericea lespedeza genotypes at 2 planting depths (1 and $3 \mathrm{~cm}$ ) at Tallassee, Ala., 1990 and 1991.

\begin{tabular}{|c|c|c|c|c|c|c|}
\hline Source & $\mathrm{df}$ & Emergence & Height & Shoot weight & Stem weight & Leaf weight \\
\hline Years (Y) & 1 & 32,609 & 6 & 628,182 & 30,930 & 380,328 \\
\hline $\operatorname{Rep} / Y$ & 6 & 1,011 & 16,250 & 259,591 & 23,902 & 143,080 \\
\hline Depth (D) & 1 & 1,607 & 14,786 & 145,968 & 11,842 & 74,657 \\
\hline $\mathrm{Y} \times \mathrm{D}$ & 1 & 776 & 1,623 & 68,620 & 15,510 & 18,168 \\
\hline Error (a) & 6 & 1,749 & 13,910 & 125,902 & 18,411 & 55,180 \\
\hline Genotypes (G) & 53 & $176^{* *}$ & $1,721^{* *}$ & $27,006^{* *}$ & $1,865^{* *}$ & $15,474^{* *}$ \\
\hline $\mathrm{Y} \times \mathrm{G}$ & 53 & $106^{* *}$ & $1,060^{* *}$ & $12,242^{* *}$ & $1,157^{* *}$ & $6,147^{* *}$ \\
\hline$D \times G$ & 53 & 59 & 578 & 6,430 & 561 & 3,503 \\
\hline $\mathrm{Y} \times \mathrm{D} \times \mathrm{G}$ & 53 & 57 & 567 & 4,512 & 411 & 2,541 \\
\hline Error (b) & 596 & 61 & 561 & 6,296 & 621 & 3,285 \\
\hline
\end{tabular}

*,**Significant at $P<0.05$, and 0.01 , respectively.

$\mathrm{cm}$ deep in each of 7 Cone-tainers (Ray Leach Cone-Tainer Nursery, Canby, Ore. 97103) $)^{1}, 4 \mathrm{~cm}$ diameter by $21 \mathrm{~cm}$ deep, filled with 0.16 liter potting soil (13\% peatmoss, $57 \%$ fine sandy loam soil, and $30 \%$ sand). After emergence, each individual Cone-tainer was thinned to 1 seedling. Trays containing the Cone-tainers were placed in growth chambers with temperature maintained at $26 / 22^{\circ}$ C (13/11 hours). A mixture of fluorescent and incandescent lamps provided a photosynthetic flux photon density during daylight of $380 \mu \mathrm{mol} \mathrm{m} \mathrm{m}^{-2}$. Water was added only when the soil surface became dry.

The study was conducted in a split plot arrangement of treatments in a randomized complete block design with 3 replications (chambers). Main plots were the genotypes and the split plots were 2 sampling dates (17 and 31 days after planting). Three random seedlings per replicate from each genotype were harvested at each date. Height and stem and leaf weights were measured on each seedling. Stem and leaf weights were added to get shoot weight.

Data from field and growth chamber experiments were subjected to analysis of variance. Seedling growth under field conditions was related to seedling traits observed in the growth chamber by simple regression as a means of evaluating the growth chamber measurements as predictors. Correlations among seed weight and seedling variables were also obtained.

\section{Results and Discussion}

\section{Field Experiments}

Main effect of planting depth and year $X$ planting depth interaction were not significant for emergence, height, shoot weight, stem weight, and leaf weight (Table 1). These results indicate that the 3-cm planting depth in sericea lespedeza did not reduce emergence or other seedling traits when compared to those at $1 \mathrm{~cm}$, thus, contradicting the report by Moore (1943). The difference may be due to the improved sericea lespedeza genotypes used in this experiment or to some environmental factors. Lack of planting depth effects on seedling vigor has also been reported in other forage legumes (Black 1956, Williams 1967).

All seedling traits differed among the genotypes $(P<0.05)$ and year $\times$ genotype interactions $(P<0.01)$ indicated that the genotypes differed somewhat between the 2 years (Table 1). Genotypes 'Serala', 73-162-16, AU L2, AU L13, and 'Serala 76', however, consistently ranked among the top $20 \%$ for shoot and leaf weights in both years (Table 2). Although seedling vigor for some genotypes differed over years, other genotypes were relatively insensitive to changes in environmental conditions (data not presented) and, therefore, could be expected to produce consistent results over a variety of planting conditions.

Seed weight was not correlated with any seedling traits in the 1990 experiment, but was correlated $(P<0.05)$ with height $(r=$ 0.32 ), shoot weight ( $r=0.51)$, stem weight $(r=0.48)$, and leaf weight
Table 2. Average height and shoot, stem, and leaf weights of selected genotypes of sericea lespedeza measured at 60 days after planting at Tallassee, Alabama, in 1990 and 1991.

\begin{tabular}{lcccc}
\hline \hline Genotype & Height & $\begin{array}{l}\text { Shoot } \\
\text { weight }\end{array}$ & $\begin{array}{c}\text { Stem } \\
\text { weight }\end{array}$ & $\begin{array}{c}\text { Leaf } \\
\text { weight }\end{array}$ \\
\hline 1990 Experiment & $-\mathrm{mm}-$ & $\cdots$ & & \\
Serala & 131 & 260 & 84 & 177 \\
$73-162-16$ & 122 & 168 & 111 & 57 \\
AU L2 & 120 & 204 & 53 & 151 \\
AU L13 & 113 & 194 & 54 & 140 \\
Serala 76 & 103 & 182 & 53 & 129 \\
1991 Experiment & & & & \\
Serala & 118 & 270 & 77 & 193 \\
73-162-16 & 132 & 349 & 99 & 249 \\
AU L2 & 126 & 292 & 78 & 214 \\
AU L13 & 142 & 391 & 110 & 280 \\
Serala 76 & 121 & 276 & 70 & 206 \\
\hline
\end{tabular}

$(r=0.51)$ in the 1991 experiment. Although the relationship of seed weight to seedling traits in sericea lespedeza was neither close nor consistent over years, seedlings from larger-seeded genotypes may have advantages over those from smaller-seeded genotypes for seedling vigor (Wulff 1986).

\section{Growth Chamber Experiment}

Differences were found among 54 genotypes for 3 of 4 seedling traits (Table 3). Sampling date accounted for most of the variability, however, none of the interactions between genotypes and

Table 3. Mean squares for seedling traits of 54 sericea lespedeza genotypes measured at 17 and 31 days after planting in a growth chamber.

\begin{tabular}{lrcccc}
\hline \hline Source & df & Height & $\begin{array}{c}\text { Shoot } \\
\text { weight }\end{array}$ & $\begin{array}{c}\text { Leaf } \\
\text { weight }\end{array}$ & $\begin{array}{c}\text { Stem } \\
\text { weight }\end{array}$ \\
\hline Replications & 2 & 1,795 & 621 & 362 & 35 \\
Genotypes (G) & 53 & $324^{* *}$ & $107^{*}$ & $64^{*}$ & 7 \\
Error (a) & 106 & 129 & 73 & 38 & 6 \\
Dates (D) & 1 & $132,126^{* *}$ & $33,488^{* *}$ & $17,516^{* *}$ & $2,560^{*}$ \\
G $\times$ D & 53 & 119 & 71 & 41 & 4 \\
Error (b) & 108 & 95 & 63 & 34 & 5 \\
\hline
\end{tabular}

*,**Significant at $P<0.05$, and 0.01 , respectively.

sampling date were significant. These results indicate that seedling traits were consistent between 17 and 31 days after planting, and seedling trait variables could be measured at either date.

Seed weight was correlated $(P<0.05)$ with all seedling traits at both 17 and 31 days after planting (Table 4). The correlation coefficients for seed weight obtained at 17 days after planting were larger than those at $\mathbf{3 1}$ days after planting. These results indicate 
Table 4. Correlation coefficients ( $r$ ) between mean seed welght and mean seedling traits of 54 sericea lespedeza genotypes measured at 17 and 31 days after planting in a growth chamber.

\begin{tabular}{llccc}
\hline $\begin{array}{l}\text { Seed or seedling } \\
\text { variables }\end{array}$ & Height & $\begin{array}{c}\text { Shoot } \\
\text { weight }\end{array}$ & $\begin{array}{c}\text { Stem } \\
\text { weight }\end{array}$ & $\begin{array}{c}\text { Leaf } \\
\text { weight }\end{array}$ \\
\hline 17 days after planting & & & & \\
Seed weight & $0.32^{*}$ & $0.64^{* *}$ & $0.54^{* *}$ & $0.66^{* *}$ \\
Height & & $0.68^{* *}$ & $0.80^{* *}$ & $0.60^{* *}$ \\
Shoot weight & & & $0.92^{* *}$ & $0.98^{* *}$ \\
Stem weight & & & & $0.85^{* *}$ \\
31 days after planting & & & & \\
Seed weight & $0.27^{*}$ & $0.43^{* *}$ & $0.42^{* *}$ & $0.42^{* *}$ \\
Height & & $0.75^{* *}$ & $0.87^{* *}$ & $0.70^{* *}$ \\
Shoot weight & & & $0.94^{* *}$ & $0.99^{* *}$ \\
Stem weight & & & & $0.94^{* *}$ \\
\hline
\end{tabular}

*,Significantly differs from zero at $P<0.05$ and 0.01 , respectively.

that genotypes with heavier seeds produced more vigorous seedlings, and the relationship between seed weight and seedling vigor was more pronounced in the earlier growth stage. The positive relationship between seed weight and seedling growth found in this experiment was similar to the finding reported by Cope (1966).

All seedling traits were correlated $(P<0.01)$ with each other (Table 4), indicating a high proportionality existed among plant parts especially for leaf and stem weights and, therefore, shoot weight. We conclude that any of the seedling traits measured could be used to represent seedling vigor.

\section{Prediction of Field Performance}

Height of seedlings of genotypes measured at 17 days after planting in the growth chamber were significantly $(P<0.05)$ correlated with seedling height measured in the 1990 field experiment, and were correlated with all seedling traits measured in the 1991 field experiment (Table 5). Stem weight measured at 17 days after planting in the growth chamber was not correlated with any seedling trait measured in the 1990 field experiment but was correlated with all seedling traits measured in the 1991 field experiment. Leaf weight and shoot weight measured at 17 days after planting in the growth chamber were correlated $(P<0.05)$ with most seedling traits measured at 60 days after planting in both 1990 and 1991 field experiments, with the exception of seedling height measured in the 1990 field experiment. No seedling traits measured at 31 days after planting in the growth chamber were correlated with any of those measured in the 1990 field experiment, but all seedlings traits measured at 31 days after planting in the growth chamber were correlated with those measured in the 1991 field experiment.
Table 6. Coefficients of determination $\left(R^{2}\right)$ from single and multiple regressions used to predict seedling traits of sericea lespedeza measured at 60 days after planting in the 1991 field experiment.

\begin{tabular}{|c|c|c|c|c|}
\hline \multirow{2}{*}{$\begin{array}{l}\text { Variables in } \\
\text { growth chamber } \dagger\end{array}$} & \multicolumn{4}{|c|}{ Variables in field } \\
\hline & Height & Shoot weight & Stem weight & Leaf weight \\
\hline SW & 0.129 & 0.298 & 0.278 & 0.293 \\
\hline H & 0.188 & 0.112 & 0.128 & 0.101 \\
\hline SDW & 0.161 & 0.186 & 0.170 & 0.185 \\
\hline LDW & 0.236 & 0.409 & 0.297 & 0.436 \\
\hline SHDW & 0.240 & 0.367 & 0.283 & 0.385 \\
\hline SW, H & 0.242 & 0.326 & 0.318 & 0.316 \\
\hline SW, SDW & 0.191 & 0.327 & 0.303 & 0.323 \\
\hline SW, LDW & 0.238 & 0.436 & 0.347 & 0.456 \\
\hline SW, SHDW & 0.243 & 0.410 & 0.342 & 0.421 \\
\hline H, SDW & 0.196 & 0.187 & 0.172 & 0.187 \\
\hline H, LDW & 0.267 & 0.412 & 0.299 & 0.445 \\
\hline H, SHDW & 0.259 & 0.378 & 0.283 & 0.404 \\
\hline SW, H, SDW & 0.242 & 0.330 & 0.318 & 0.323 \\
\hline SW, H, LDW & 0.273 & 0.437 & 0.352 & 0.462 \\
\hline SW, H, SHDW & 0.267 & 0.414 & 0.345 & 0.431 \\
\hline H, SDW, LDW & 0.238 & 0.465 & 0.327 & 0.506 \\
\hline SW, H, SDW, & 0.312 & 0.490 & 0.380 & 0.522 \\
\hline
\end{tabular}

$\lceil$ Measured at 17 days after planting in the growth chamber experiment. † Seed weight (SW), height $(\mathrm{H})$, stem weight (SDW), leaf weight (LDW), and shoo weight (SHDW).

Seed weight and seedling traits measured 17 days after planting in the growth chamber experiment were used as independent variables in multiple regressions to predict seedling traits measured in the 1991 field experiment (Table 6). Shoot weight in the growth chamber experiment provided the best single-variable estimate of height and leaf weight at 60 days after planting in the 1991 field experiment. Leaf weight measured in the growth chamber was the best single independent variable to estimate both shoot weight and stem weight in the field. When 2 or more independent variables were included in the equations, there were only small increases in $\mathbf{R}^{2}$ values (Table 6). Seed weight and seedling traits measured in the growth chamber could be used to give an estimation of field performance; however, the variables measured accounted for a maximum of only $52 \%$ of the variation. Therefore, measurement of seedling traits under the growth chamber conditions may not provide a reliable estimate of seedling vigor under field conditions in sericea lespedeza. However, genotypes 73-162-16, AU L2, AU L13, and 'Serala 76' consistently ranked among the top $20 \%$ for shoot weight in the growth chamber and in both years in the field.

Table 5. Correlation coefficients (r) between height (H), stem weight (SDW), leaf weight (LDW) and shoot weight (SHDW) measured at 17 and 31 days after planting in the growth chamber experiment and at 60 days after planting in the 1990 and 1991 field experiments.

\begin{tabular}{|c|c|c|c|c|c|c|c|c|}
\hline \multirow{2}{*}{$\begin{array}{l}\text { Chamber } \\
\text { variables }\end{array}$} & \multicolumn{4}{|c|}{ Field 1990} & \multicolumn{4}{|c|}{ Field 1991} \\
\hline & $\mathbf{H}$ & SDW & LDW & SHDW & $\mathbf{H}$ & SDW & LDW & SHDW \\
\hline \multicolumn{9}{|c|}{$\begin{array}{l}\text { Chamber } \\
17 \text { days after planting }\end{array}$} \\
\hline H & $0.29^{*}$ & 0.23 & 0.17 & 0.20 & $0.43^{*}$ & $0.36^{*}$ & $0.32^{*}$ & $0.33^{*}$ \\
\hline SDW & 0.21 & 0.24 & 0.19 & 0.21 & $0.40^{*}$ & $0.41^{*}$ & $0.43^{*}$ & $0.43^{*}$ \\
\hline LDW & 0.24 & $0.28 *$ & $0.37^{*}$ & $0.35^{*}$ & $0.49^{*}$ & $0.54^{*}$ & $0.66^{*}$ & $0.64^{*}$ \\
\hline SHDW & 0.25 & $0.27^{*}$ & $0.33^{*}$ & $0.32 *$ & $0.49 *$ & $0.53^{*}$ & $0.62^{*}$ & $0.61^{*}$ \\
\hline \multicolumn{9}{|c|}{31 days after planting } \\
\hline $\mathbf{H}$ & $0.20^{-}$ & 0.03 & 0.05 & 0.05 & $0.50^{*}$ & $0.35^{*}$ & $0.30^{*}$ & $0.32^{*}$ \\
\hline SDW & 0.16 & 0.03 & 0.09 & 0.08 & $0.46^{*}$ & $0.39 *$ & $0.38^{*}$ & $0.39^{*}$ \\
\hline LDW & 0.16 & 0.07 & 0.21 & 0.18 & $0.38^{*}$ & $0.40^{*}$ & $0.49^{*}$ & $0.47^{*}$ \\
\hline SHDW & 0.16 & 0.06 & 0.18 & 0.15 & $0.41^{*}$ & $0.41^{*}$ & $0.47^{*}$ & $0.46^{*}$ \\
\hline
\end{tabular}

*Significantly differs from 0 at $P<0.05$. 


\section{Summary and Conclusions}

There is substantial variability among sericea lespedeza genotypes for traits that can be used in a breeding program to improve seedling vigor. Genotypes 73-162-16, AU L2, AU L13, and 'Serala 76' outperformed other genotypes for most seedling traits under field and growth chamber conditions. Planting at $3 \mathrm{~cm}$ deep did not reduce emergence and seedling growth compared to $1 \mathrm{~cm}$ and, therefore, may be recommended in sandy loam soils when there is insufficient moisture in the upper soil layer at planting time. Although measurements taken in the growth chamber did not reliably predict field performance, information gathered in the growth chamber provides a good means of increasing the frequency of superior plants to be tested in the field.

\section{Literature Cited}

Beaveridge, J.L., and C.P. Wilsie. 1959. Influence of depth of planting, seed size and variety on germination and seedling vigor in alfalfa. Agron. J. 51:731-734.

Black, J.N. 1956. The influence of seed size and depth of sowing on preemergence and early vegetative growth of subterranean clover (Trifolium subterraneum L.). Aust. J. Agr. Res. 7:98-109.

Black, J.N. 1957. The early vegetative growth of three strains of subterranean clover (Trifolium subterraneum L.) in relation to size of seed. Aust. J. Agr. Res. 8:1-14.

Carren, C.J., A.M. Wilson, R.L. Cuany, and G.L. Thor. 1987a. Caryopsis weight and planting depth of blue grama. I. Morphology, emergence, and seedling growth. J. Range Manage. 40:207-211.
Carren, C.J., A.M. Wilson, and R.L. Cuany. 1987b. Caryopsis weight and planting depth of blue grama. II. Emergence in marginal soil moisture. J. Range Manage. 40:212-216.

Cooper, C.S., M.A. Hughes, and R.L. Ditterline. 1980. Seedling length day 3-a simple rapid technique for evaluating seedling vigor of birdsfoot trefoil. J. Seed Tech. 5:17-25.

Cope, W.A. 1966. Growth rate and yield in sericea lespedeza in relation to seed size and outcrossing. Crop Sci. 6:566-568.

Moore, R.P. 1943. Seedling emergence of small-seeded legumes and grasses. J. Amer. Soc. Agron. 35:370-381.

Mosjidis, J.A. 1990. Daylength and temperature effects on emergence and early growth of sericea lespedeza. Agron. J. 82:923-926.

Peiffer, R.A., G.W. McKee, and M.L. Risiu. 1972. Germination and emergence of crownvetch as affected by seed maturity and depth of planting. Agron. J. 64:772-774.

Tischler, C.R., and P.W. Voigt. 1983. Effects of planting depth on vegetative characteristics of three forage grasses at 14 days post-emergence. Crop Sci. 23:481-484.

Townsend, C.E., and W.J. McGinnies. 1972. Establishment of nine forage legumes. Agron. J. 64:699-702.

Townsend, C.E. 1979. Associations among seed weight, seedling emergence, and plant depth in cicer milkvetch. Agron. J. 71:410-414.

Twamley, B.E. 1967. Seed size and seedling vigor in birdsfoot trefoil. Can. J. Plant Sci. 47:603-609.

Williams, W.A. 1967. Seedling growth of a hypogeal legume, Vicia dasycarpa, in relation to seed weight. Crop Sci. 7:163-165.

Wulff, R.D. 1986. Seed size variation in Desmodium paniculatum. II. Effects on seedling growth and physiological performance. J. Ecology. 74:99-114. 